A Global History of Gold Rushes 
THE CALIFORNIA WORLD HISTORY LIBRARY

Edited by Edmund Burke III, Kenneth Pomeranz, and Patricia Seed

I. The Unending Frontier: Environmental History of the Early Modern World, by John F. Richards

2. Maps of Time: An Introduction to Big History, by David Christian

3. The Graves of Tarim: Genealogy and Mobility across the Indian Ocean, by Engseng Ho

4. Imperial Connections: India in the Indian Ocean Arena, I860-1920, by Thomas R. Metcalf

5. Many Middle Passages: Forced Migration and the Making of the Modern World, edited by Emma Christopher, Cassandra Pybus, and Marcus Rediker

6. Domesticating the World: African Consumerism and the Genealogies of Globalization, by Jeremy Prestholdt

7. Servants of the Dynasty: Palace Women in World History, edited by Anne Walthall

8. Island World: A History of Hawai' $i$ and the United States, by Gary Y. Okihiro

9. The Environment and World History, edited by Edmund Burke III and Kenneth Pomeranz

Io. Pineapple Culture: A History of the Tropical and Temperate Zones, by Gary Y. Okihiro

II. The Pilgrim Art: Cultures of Porcelain in World History, by Robert Finlay

12. The Quest for the Lost Nation: Writing History in Germany and Japan in the American Century, by Sebastian Conrad; translated by Alan Nothnagle

13. The Eastern Mediterranean and the Making of Global Radicalism, 1860-1914, by Ilham Khuri-Makdisi

14. The Other West: Latin America from Invasion to Globalization, by Marcello Carmagnani

15. Mediterraneans: North Africa and Europe in an Age of Migration, c. I800-1900, by Julia A. Clancy-Smith

16. History and the Testimony of Language, by Christopher Ehret 
17. From the Indian Ocean to the Mediterranean: The Global Trade Networks of Armenian Merchants from New Julfa, by Sebouh David Aslanian

18. Berenike and the Ancient Maritime Spice Route, by Steven E. Sidebotham

19. The Haj to Utopia: The Ghadar Movement and Its Transnational Connections, Igos-1930, by Maia Ramnath

20. Sky Blue Stone: The Turquoise Trade in World History, by Arash Khazeni

21. Pirates, Merchants, Settlers, and Slaves: Colonial America and the Indo-Atlantic World, by Kevin P. McDonald

22. Black London: The Imperial Metropolis and Decolonization in the Twentieth Century, by Marc Matera

23. The New World History: A Field Guide for Teachers and Researchers, edited by Ross E. Dunn, Laura J. Mitchell, and Kerry Ward

24. Margins of the Market: Trafficking and Capitalism across the Arabian Sea, by Johan Mathew

25. A Global History of Gold Rushes, edited by Benjamin Mountford and Stephen Tuffnell 
The publisher and the University of California Press Foundation gratefully acknowledge the generous support of the Peter Booth Wiley Endowment Fund in History. 


\title{
A Global History of Gold Rushes
}

\author{
EDITED BY
}

Benjamin Mountford and Stephen Tuffnell

甲 
University of California Press, one of the most distinguished university presses in the United States, enriches lives around the world by advancing scholarship in the humanities, social sciences, and natural sciences. Its activities are supported by the UC Press Foundation and by philanthropic contributions from individuals and institutions. For more information, visit www.ucpress.edu.

University of California Press

Oakland, California

(c) 2018 by The Regents of the University of California

Cataloging-in-Publication data for this title is on file with the Library of Congress

ISBN $978-0-520-29454-7$

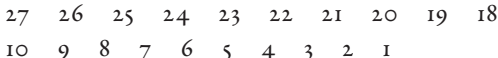

Cover images - complete captions and credit information

Left image: Simmons (mining agent, law agent, and public accountant) and family outside his bark hut, Gulgong area, New South Wales, circa 1870-5. American \& Australasian Photographic Company, ON 4 Box 4 No 18368. Mitchell Library, State Library of New South Wales.

Center image: View of San Francisco Harbor, I851. McIntyre, Sterling C., photographer. Half-plate daguerreotype, DAG no. 1330. Library of Congress Prints and Photographs Division.

Right image: An African-American miner and a Chinese miner working underground at Bendigo, Victoria, Australia. This image was probably taken underground at the Catherine Reef Claimholders Company mine in the late I880s. Photograph courtesy of James Lerk, with assistance from Colin Barr. Originally from the F.W. Palmer collection. 
For the late, great Jan-Georg Deutsch (1956-2016) 
Destruction fang mankind. Earth, yield me roots.

\section{He digs}

Who seeks for better of thee, sauce his palate

With thy most operant poison.

He finds gold

What is here?

Gold? Yellow, glittering, precious gold?

No, gods, I am no idle votarist:

Roots, you clear heavens. Thus much of this will make

Black white, foul fair, wrong right,

Base noble, old young, coward valiant.

Ha, you gods! Why this, what, this, you gods? Why, this

Will lug your priests and servants from your sides,

Pluck stout men's pillows from below their heads.

This yellow slave

Will knit and break religions, bless th' accursed,

Make the hoar leprosy adored, place thieves,

And give them title, knee, and approbation

With senators on the bench. This is it

That makes the wappered widow wed again.

She whom the spittle house and ulcerous sores

Would cast the gorge at, this embalms and spices

To th' April day again. Come, damnèd earth,

Thou common whore of mankind, that puts odds

Among the rout of nations; I will make thee

Do thy right nature.

WILLIAM SHAKESPEARE

AND THOMAS MIDDLETON,

Timon Of Athens, Act 4, Scene 3

From Stanley Wells and Gary Taylor, eds., The Oxford Shakespeare: The Complete Works, (New York: Oxford University Press, 1998 [1988]), 899. 